\title{
Mental health in times of COVID-19. Technology as a supporting tool
}

\section{Salud mental en tiempos de COVID-19. La tecnología como herramienta de soporte}

\author{
Dayara A. Barrios-Borjas, * Valeria A. Béjar-Ramos and Vania S. Cauchos-Mora \\ Universidad Nacional San Luis Gonzaga, Faculty of Human Medicine, Scientific Society of Medical Students, Ica, Peru
}

As a result of the outbreak of the new coronavirus, SARS-CoV-2, and its declaration as a pandemic by the World Health Organization, global health systems have established measures of social isolation and border closures in order to reduce the spread of the virus. This situation generates anguish and anxiety in the population, which requires urgent measures of support and psychological help. ${ }^{1}$

Preliminary studies describe that medical personnel suffers "emotional trauma" episodes due to the high risk of infection, protective equipment deficit, overwork, discrimination and isolation, which impacts on their decision-making and correct labor performance. In the general population, post-traumatic stress disorder symptoms have increased from 4 to $41 \%$, depression is observed in $7 \%$, and cases of self-medication poisoning have been reported. ${ }^{2}$

In current situation, technology allows greater access to emotional support, through the use from mobile phone apps, to courses and free online counseling, in order to help understand and control the emotions generated by confinement. Various countries have incorporated services for emergency intervention in cases of psychological crises: in Peru, psychological care and first aid measures have been proposed for health personnel; experts in the field have been called in Chile and Brazil, and recommendations, mobile applications and helplines have been generated, arranged by risk groups, in order to maintain the humanity of the response team, provide clear information and not generating panic., ${ }^{1,3,4}$ Although apps or remote counseling do not fully replace personal care, their use has shown benefits in chronic diseases, in addition to some advantages: less saturation in health facilities, less exposure to the virus and reduction in the cost of care..$^{4,5}$

A systematic search was conducted in Android and Apple app stores, as well as Google, looking for apps and online course platforms until June, using the key terms "salud mental", "coronavirus", "COVID-19" and "aplicaciones", as well as their translations into English (mental health, coronavirus, COVID-19 and apps). Those that address mental health as the main topic, that were access-free, created during the current pandemic and that can be used regardless of the geographical area of residence, were registered (Table 1). Although technological support is not yet ideal, efforts are being made to strengthen these services that complement medical care.

The COVID-19 outbreak has shown that comprehensive deployment of an emergency system for psychological intervention is required in case of epidemics, which have negative effects on people's mental health, even on those without prior mental disorders. ${ }^{5}$ Today more than ever it is evident that collective effort and comprehensive support will be decisive to face one of the most important health challenges of recent times. 
Table 1. Apps and online courses about COVID-19 and mental health

\begin{tabular}{|l|l|l|l|}
\hline Name & Supplier & Language & Description \\
\hline Here for You-Snapchat & Snap Inc & $\begin{array}{l}\text { English- } \\
\text { Spanish }\end{array}$ & $\begin{array}{l}\text { Offers local experts' information to users looking for mental } \\
\text { health-related information. }\end{array}$ \\
\hline Gestioemocional.cat & Catalonian Health Service & $\begin{array}{l}\text { Spanish } \\
\text { COVID Coach }\end{array}$ & $\begin{array}{l}\text { Evaluation and access to emotional resources by means of } \\
\text { the use of questionnaires. }\end{array}$ \\
\hline Jenny & $\begin{array}{l}\text { National Center for } \\
\text { Post-Traumatic Stress } \\
\text { Disorder-United States }\end{array}$ & English & $\begin{array}{l}\text { Exercises to cope with stress and anxiety during } \\
\text { confinement. }\end{array}$ \\
\hline Mindful, S.A.P.I. de C.V. & Spanish & $\begin{array}{l}\text { It includes a special COVID-19 module that offers the users } \\
\text { guidance to deal with emotional symptoms caused by } \\
\text { confinement }\end{array}$ \\
\hline
\end{tabular}

\section{Online courses}

Primera Ayuda Psicológica (PAP) Pan-American Health en el manejo de emergencias (COVID-19)-2020

Mental and Behavioral Health:

COVID-19 Healthcare Hub

Resilience Skills in a Time of Uncertainly

Mind Control: Managing your Mental Health During COVID-19

Primeros Auxilios

Psicológicos (PAP)-Edición especial COVID-19

\section{COVID19: Comunicarnos Sin} Daño Durante la Pandemia

COVID-19: Psychological Impact, Wellbeing and Mental Health

Anxiety in Children and Young People during COVID-19

COVID-19: Helping Young People Manage Low Mood and Depression

Motivation and Engagement in an Uncertain World

Managing Mental Health and Stress

Work-Life Balance and the Impact of Remote Working

Social Care during COVID-19: Coping with Self-Isolation and Social Distancing
Organization

Elsevier Publishing House English

University of Pennsylvania English

University of Toronto

Universidad Autónoma de Spanish

Barcelona

Pontificia Universidad

Javeriana

Maudsley Learning

University of East Anglia

University of Reading

Coventry University

Coventry University

Coventry University

The Tavistock and Portman English NHS Foundation Trust

Spanish
Aimed at the general public, it focuses on detection and initial management of psychological emergencies within the context of the pandemic

Aimed at health professionals, it provides training in the main mental health topics

Aimed at the general public, it incorporates resilience into personal and professional life during the pandemic

English- Aimed at the general public, it provides support to cope with Spanish anxiety in times of social isolation.

Aimed at health professionals and the public in general, to effectively respond to the emotional impact caused by the pandemic.

Spanish Aimed at the general public, it addresses communication and how it affects mental health.

English Directed to the general public, it addresses the personal and social impact caused by COVID19.

English Aimed at health professionals and the general public, it addresses strategies in cases of anxiety in young people.

English Aimed at the general public to help young people adapt during the pandemic.

English Aimed at the general public to cope with the impact of the pandemic.

English Aimed at the general public on the effects of social isolation.

English Aimed at the general public to mitigate the effects of remote work.

Aimed at vulnerable groups' caregivers, for the management of social isolation.

\section{References}

1. World Health Organization [Internet]. Switzerland: Mental health considerations during COVID-19 outbreak; 2020.

2. Torales J, O'Higgins M, Castaldelli-Maia JM, Ventriglio A. The outbreak of COVID-19 coronavirus and its impact on global mental health. Int $J$ Soc Psychiatry. 2020;66:317-320.

3. Duan L, Zhu G. Psychological interventions for people affected by the COVID-19 epidemic. Lancet Psychiatry. 2020;7:300-302.

4. Banskota S, Healy M, Goldberg EM. 15 smartphone apps for older adults to use while in isolation during the COVID-19 pandemic. West J Emerg Med. 2020;21:514ロ525.

5. Ministerio de Salud. Guía técnica para el cuidado de la salud mental del personal de la salud en el contexto del Covid-19. Peru: Ministerio de Salud; 2020. 